\author{
N.A. Kremlyova, A.A. Borisov, A.A. Frolov
}

\title{
A CREATIVE MODEL FOR GRAPHICAL DESIGN OF CONVERSION PROCESSES IN ENGINEERING BUSINESS
}

\author{
Н.А. Кремлёва, А.А. Борисов, А.А. Фролов \\ КРЕАТИВНАЯ МОДЕЛЬ ГРАФИЧЕСКОГО ПРОЕКТИРОВАНИЯ \\ ПРОЦЕССОВ КОНВЕРСИИ В ИНЖЕНЕРНОМ БИЗНЕСЕ
}

Innovation processes are a tool for quantitative and qualitative assessment and subsequent improvement of the efficiency of the engineering business. To accomplish this task, we have developed a creative graphical model based on the principle of converting the manufacturing capital into its money equivalent in the form of sales volume. The graphical interpretation of the closed operating cycle of conversion (OCC) in a manufacturing-technological system (MTS) is implemented in a triangle coordinate system including five cash flow vectors: sales volume; manufacturing capital; technological costs; net income; main funds (sum of tangible and intangible assets). The theoretical principles and the architecture of the parameters of the engineering business have been formulated on the basis of examining the OCC parametrical equation in a triangle coordinate system. We have obtained the following results: in a real engineering business the conversion criterion of an operating cycle (the relation of sales volume to manufacturing capital) is less than unity; in an ideal operating cycle this criterion is equal to unity, and exceeds unity in excise business. Accordingly, the net income in a real operating cycle is less than the technological costs, and they are equal in an ideal operating cycle, and the net income is more than the technological costs in excise business. The main funds of a manufacturing-technological system in a real operating cycle are more than the net income, they are equal in an ideal cycle, and the main funds of an MTS are less than the net income in excise engineering business. The task of innovating projects is to create the architecture for the parameters of operation cycle conversion in an MTS providing an increase in the investment attractiveness of engineering business on the stock market.

CONVERTING MANUFACTURING CAPITAL; CLOSED OPERATING CYCLE; CONVERSION CRITERION; CAPITALIZATION OF TECHNOLOGICAL COSTS; MAIN FUNDS MANUFACTURING TECHNOLOGICAL SYSTEM OF ENGINEERING BUSINESS.

Инновационные процессы являются инструментом количественной и качественной оценки эффективности инженерного бизнеса и последующего совершенствования его эффективности. Для реализации этой задачи разработана проектно-графическая модель, в основу которой положен принцип конверсии производственного капитала в его денежный эквивалент в форме проданной продукции. Графическая интерпретация замкнутого операционного цикла конверсии (ОЦК) в производственнотехнологической системе (ПТС) реализована в треугольной системе координат из пяти векторов денежных потоков: объема реализации продукции, производственного капитала, технологических затрат, чистого дохода, основных фондов (суммы материальных и нематериальных активов). На основе исследования параметрического уравнения ОЦК в треугольной системе координат сформулированы теоретические положения и архитектура параметров инженерного бизнеса. Получены следующие результаты: в реальном инженерном бизнесе критерий конверсии операционного цикла (отношение объема реализованной продукции к производственному капиталу) меньше единицы; в идеальном операционном цикле этот критерий равен единице; в акцизном бизнесе он больше единицы. Соответственно в реальном операционном цикле чистый доход меньше технологических затрат, в идеальном цикле они равны, а в акцизном бизнесе чистый доход больше технологических затрат. В реальном операционном цикле основные фонды производственно-технологической системы больше чистого дохода, в идеальном цикле они равны, а в акцизном инженерном бизнесе основные фонды ПТС меньше чистого дохода. Задачами инновационных проектов является создание архитектуры параметров операционного цикла конверсии в ПТС, обеспечивающей инвестиционную привлекательность инженерного бизнеса на фондовом рынке.

КОНВЕРСИЯ ПРОИЗВОДСТВЕННОГО КАПИТАЛА; ЗАКРЫТЫЙ ОПЕРАЦИОННЫЙ ЦИКЛ; КРИТЕРИЙ КОНВЕРСИИ; КАПИТАЛИЗАЦИЯ ТЕХНОЛОГИЧЕСКИХ ЗАТРАТ; ОСНОВНЫЕ ФОНДЫ ПРОИЗВОДСТВЕННО-ТЕХНОЛОГИЧЕСКОЙ СИСТЕМЫ ИНЖЕНЕРНОГО БИЗНЕСА.

Academic editor, creator Shichkov A.N.

Goal and objectives. Monetary flows in a closed operating cycle of an engineering business consisting of an integrated set of operational and technological processes as a result of conversion are formed as the sales volume of products. Therefore, the manufacturing performance of an 
OCC can be improved by continuously implementing innovative projects ensuring the growth of the conversion level. The conversion level is equal to the relation of the manufacturing capital to monetary capital of an enterprise received from the sold products. To implement this task in engineering enterprises, management accounting is improved based on the market structure operating as a transfer of technological costs and consumer properties of products within technological stages that are also viewed in this case as zones of financial responsibility.

Our task was to develop practical recommendations for mastering the method of graphical design of an operating cycle of conversion (OCC) in manufacturing and technological systems of engineering business.

Introduction to the theory and practice of operating cycles of conversion. Business is one of the important creative areas of human practices aimed at helping people sustain their activities [1].

The supply in engineering business determines the consumer properties of products and services in the innovative market economy. Therefore, engineering business continuously solves creative innovative tasks: what to produce and how to produce it (what manufacturing capital and technology to use) so that products and services have competitive advantages on the market and on this basis to get the biggest sales volume at the lowest technological costs and the highest income.

Many creative projects in music, visual arts, and chess, economic, technological, mathematical projects and modeling, as well as other kinds of creative activities using electronic digital systems complement the creative activity of humans, performing ordinary multivariate tasks.

The engineering business is an integrated set of manufacturing and technological systems [2] that converts manufacturing capital into its cash equivalent in the form of sales volume of products and net income necessary and sufficient for continuous investment of simple and extended reproduction of the main funds of the manufacturing capital and for paying dividends to business owners in the amount of the remaining net income.

Therefore, the economic benefits of each MTS of an engineering businessis characterized by the sales volume $V_{s v}$, rub./year, at adequate cost $Q$, rub./year of the manufacturing capital.
The concept of adequacy implies the possibility and capability of the manufacturing capital to yield products with competitive advantages and in the amount needed on the market.

For this purpose, the production system of the engineering business should be organized and implemented based on the transfer of technological costs $G_{0} W_{0}$, rub./year, and consumer properties (market value) of products within technological stages. Only in this case, the end products will have competitive advantages and will be sold at a price equal to or above its market value [3].

In addition, each manufacturing and technological system (MTS) is a zone of financial responsibility (ZFR) including a minimal integrated set of tangible and intangible assets and manufacturing (outputting) technological stages or end products with a market cost.

The sales volume should cover the sum of technological costs $G_{0} W_{0}$, rub./year, (where $G_{0}$ is the volume of manufactured products in natural parameters, for example, units/year; and in this case, unit costs $W_{0}$, rub./units) and should provide a net income $D_{0}$, rub./year, including the annual depreciation (amortization) of tangible assets $C_{t a}$, rub./year, the annual amortization of intangible assets $C_{i a}$, rub./year, and the net operation profit $P_{0}$, rub./year.

This fact may be interpreted in this mathematical form:

$$
\frac{V_{s v}}{G_{0} W_{0}+D_{0}}=\frac{V_{s v}}{G_{0} W_{0}+C_{t a}+C_{i a}+P_{0}}=1 .
$$

Our research has shown [4-6] that the technological costs in the engineering business are, from the mathematical point of view, a parabola having the form:

$$
W=a G^{2}+b G+c,
$$

where the constant coefficients $a, b, c$ are constants of this manufacturing and technological system with the coordinates of the extremum (calculated parameters) $G_{0}=-b / 2 a$; $W_{0}=\left(4 a c-b^{2}\right) / 4 a$.

Each coefficient of equation (2) determines the curvature of the parabola, and, consequently, the physical basis of a technological process. Therefore, to reduce technological costs, it is necessary to change the technology. 


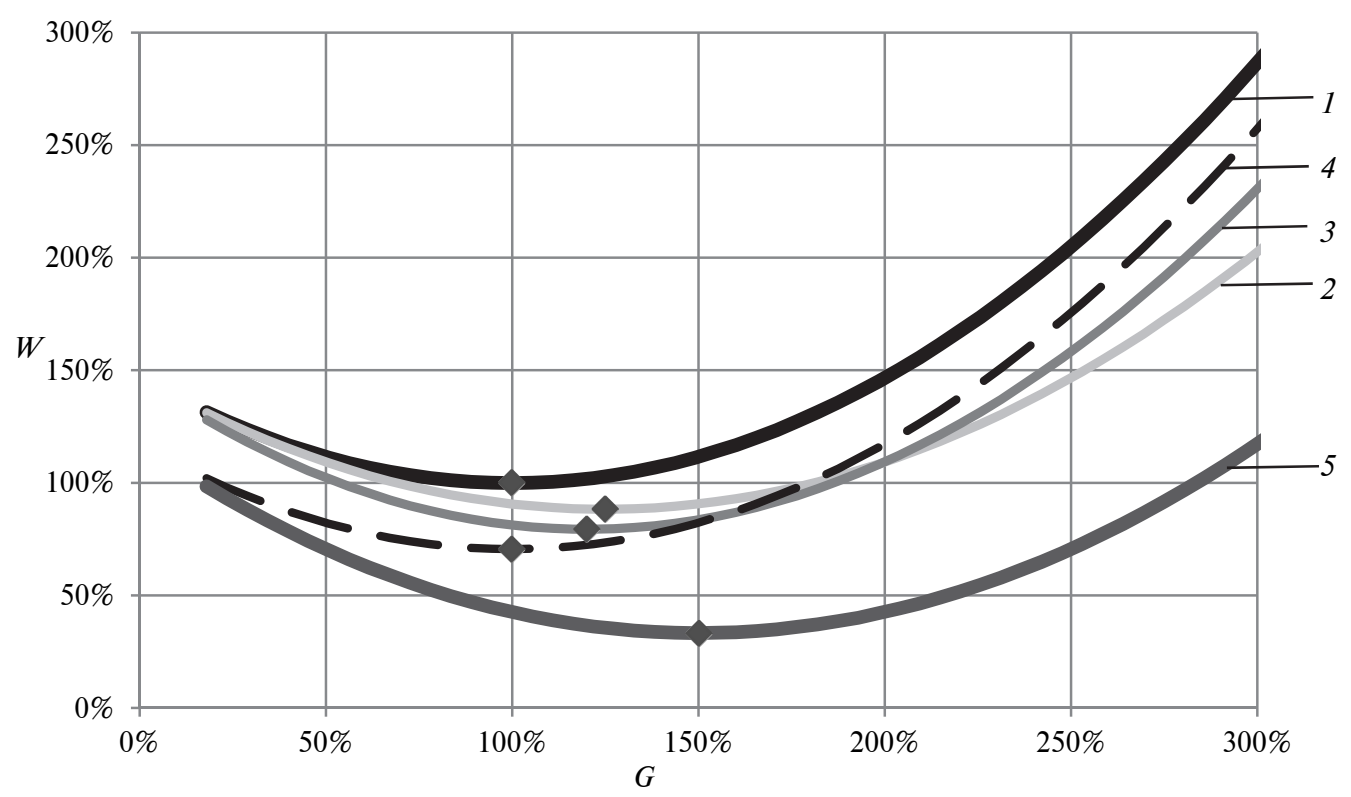

Fig. 1. Graphical interpretation of the mathematical model of technological costs in the OCC of the manufacturing capital

For example, the parabolic dependence of unit costs on manufactured and sold products of an engineering enterprise has the form [7,8]:

$$
W=3.28 \cdot 10^{-5} G^{2}-0,12 G+345.18,
$$

where the extreme points are $G_{0}=0.12 / 2 \times$ $\times 3.28 \cdot 10^{-5}=1829$ units $/$ year; $W_{0}=(4 \times$ $\left.\times 3.28 \cdot 10^{-5} \cdot 345.18-0,12^{2}\right) / 4 \cdot 3.28 \cdot 10^{-5}=$ $=235$ rub. thousands/unit.

Fig. 1 presents an initial basic parabola and three parabolas made at values $20 \%$ lower than one of the studied coefficients comparatively to its basic value ( $a$ is parabola $2 ; b$ is parabola 3 and $c$ is parabola 4) and a resultant parabola made at lesser values of all coefficients by $20 \%$ (parabola 5).

The greatest reduction of unit costs $W$ takes place when there is a change in the value of coefficient $C$, determining the downward shift of the parabola. In this case, the coordinates of the extreme points are at $0 \%$ on the $G$ axis and at $29.32 \%$ on the $W$ axis, consequently, the range of production volume remains constant.

The smallest change of unit costs and the largest increase in the manufacturing volume is achieved when we change coefficient $a$, which defines the stretching or compression of the parabola along the vertical axis. In this case, the coordinates of the extreme points of the parabola change by $25 \%$ on the $G$ axis and by $-11.66 \%$ on the $W$ axis. The parabola moves to the right and down, and its branches grow along the vertical axis. In this case, the change in the manufacturing volume of products has a lesser impact on the change of unit costs.

The case when the coefficient $b$ is changed yields intermediary results for reducing the unit costs and increasing the manufacturing volumes. This changes the coordinates of the parabola's extremum by $20 \%$ on the $G$ axis and by $20.51 \%$ on the $W$ axis, i. e. the parabola moves to the right and down.

Simultaneously decreasing the values of all coefficients is optimal with respect to expanding the ranges of the manufacturing volume and of the reduction of unit costs. The extremum then shifts by $50 \%$ on the $G$ axis and by $-66.62 \%$ on the $W$ axis.

Innovative technology may be designed on the basis of the parabola curvature required for a conversion process.

For example, instead of turning processing (blade processing) with a low material utilization ratio, it might be more effective to use hot or cold stamping, pressing, forging, hot rolling, cold rolling, powder metallurgy with high metal utilization rates.

In this sense the parabola is a creative mathematical model of technological costs in a manufacturing and technological system. 
For the purposes of management accounting and designing innovating projects [9], the money equivalent of the manufacturing capital in each manufacturing-technological system $Q$, rub./year, should be estimated by the income approach. As a matter of fact, organizing production using the transfer of technological costs and values (consumer properties of products) within the technological stages that are zones of financial responsibility is done on the basis of internal management accounting $[10,11]$.

The manufacturing capital is equal to the sum of technological costs $G_{0} W_{0}$, rub./year, and the main funds of an enterprise $U$, rub./year, including fixed assets (tangible assets) $U_{f a}$, rub./year, taxable for entity property, and intangible assets $U_{i a}$, rub./year.

The mathematical dependence of this fact has the form:

$$
\frac{Q}{G_{0} W_{0}+U_{m f}}=\frac{Q}{G_{0} W_{0}+U_{f a}+U_{i a}}=1 .
$$

We consider the engineering business as an integrated set of closed continuous OCC of the manufacturing capital $Q$ into its cash equivalent in the form of the sales volume $V_{s v}$

Consequently, to get the mathematical model of the conversion of manufacturing capital on the basis of a closed operating cycle, equation (1) should be equal to equation (3):

$$
\frac{V_{s v}}{G_{0} W_{0}+D_{0}}=\frac{Q}{G_{0} W_{0}+U_{m f}} \text {. }
$$

A parametrical equation of converting the manufacturing capital has the form:

$$
\frac{V_{s v}}{Q}=\frac{G_{0} W_{0}+D_{0}}{G_{0} W_{0}+U_{m f}} .
$$

This equation (5) has the following dimensionless form:

$$
\frac{V_{s v}}{Q}=\frac{\frac{V_{s v}}{G_{0} W_{0}}}{\frac{Q}{G_{0} W_{0}}}=\frac{\frac{G_{0} W_{0}}{U_{m f}}+\frac{D_{0}}{U_{m f}}}{\frac{G_{0} U_{0}}{U_{m f}}+1} .
$$

Our research shows [2, 3, 5] that the conversion level $\vartheta$ of manufacturing capital in the operating cycle is equal to the relation of the sales volume $V_{s v}$ to the manufacturing capital $Q$.

If the level of converting the manufacturing capital in one operating cycle is equal to another operating cycle, in this case, both engineering businesses are similar (equivalent). Consequently, the conversion level is the conversion criterion and all dimensionless complexes in equation (6) are the conversion criteria of the manufacturing capital in the operating cycle of the engineering business.

Namely,

$\vartheta=\frac{V_{s v}}{Q}$, the conversion criterion is equal to a ratio of sales volume to manufacturing capital of the engineering business;

$$
\lambda=\frac{V_{S v}}{G_{0} W_{0}} \text {, the capitalization criterion is }
$$

equal to a ratio of sales volume to technological costs of the operating cycle;

$$
\rho=\frac{Q}{G_{0} W_{0}}, \text { the resource criterion of }
$$

manufacturing capital is equal to a ratio of manufacturing capital cost to technological costs;

$$
M=\frac{D_{0}}{U_{m f}}, \text { the investment criterion is equal }
$$

to a ratio of net income to main funds;

$$
k_{0}=\frac{G_{0} W_{0}}{U_{m f}}, \text { the characteristic of a }
$$

manufacturing and technological system [5].

We will record the criteria equation (6) using the common notations of the dimensionless quantities:

$$
\vartheta=\frac{\lambda}{\rho}=\frac{k_{0}+M}{k_{0}+1} .
$$

The analysis of a conversion level in an operating cycle for three equivalent metallurgical enterprises manufacturing sheet rolling products is presented in Tab. 1 [2, 4-6]. The parameters of the investment attractiveness of enterprise are presented in the first part of Tab. 1. The calculated parameters of an operating cycle are presented in the second part; and finally, the conversion criteria are presented in the third part of Table. 
Conversion parameters of manufacturing capital in operating cycles of equivalent metallurgical enterprises

\begin{tabular}{|c|c|c|c|}
\hline Equivalent enterprises & JSC MMC & JSC NLMC & JSC Severstal \\
\hline \multicolumn{4}{|c|}{ Stock market parameters for equivalent metallurgical enterprises that manufacture steels sheets, mln USD } \\
\hline Sales volume, $V_{s v}$ & 5380.00 & 4468.73 & 5055.17 \\
\hline Return on sales, $r=P / V_{s v}$ & $24.6 \%$ & $41.6 \%$ & $35.2 \%$ \\
\hline Net profit, $P_{0}$ & 947.00 & 1385.34 & 1212.00 \\
\hline Operation profit, $P$ & 1323.48 & 1859.00 & 1779.42 \\
\hline \multicolumn{4}{|c|}{ Parameters of operation cycle } \\
\hline Operation costs $C_{o c}=V_{s v}-P$ & 4056.52 & 2609.74 & 3275.75 \\
\hline$\Delta P=P-P_{0}=N_{f a}+N_{p}$ & 376.48 & 473.66 & 567.42 \\
\hline $\begin{array}{l}\text { Tax operating profit } \\
N_{p}=P_{0} \psi_{p} /\left(1-\psi_{p}\right), \psi_{p}=0.2\end{array}$ & 236.75 & 348.34 & 303.00 \\
\hline Tax fixed assets $N_{f a}=\Delta P-N_{p}$ & 139.73 & 125.32 & 264.42 \\
\hline Fixed assets $U_{f a}=N_{f a} / \psi_{f a}, \psi_{f a}=0.02$ & 6986.50 & 6266.00 & 13221.00 \\
\hline Depreciation costs $C_{d c}=0,03 U_{f a}$ & 209.60 & 188.00 & 396.63 \\
\hline Direct technological costs $G_{0} W_{0}=C_{o c}-C_{d c}$ & 3846.92 & 2421.74 & 2879.12 \\
\hline Net income $D_{0}=P_{0}+C_{d c}$ & 1156.60 & 1573.34 & 1608.63 \\
\hline $\begin{array}{l}\text { Sales volume } V_{s v}=G_{0} W_{0}+D_{0} \\
V_{s v} / V_{s v}^{\prime}\end{array}$ & $\begin{array}{c}5003.52 \\
(0.93)\end{array}$ & $\begin{array}{c}3995.08 \\
(0.89)\end{array}$ & $\begin{array}{l}4487.75 \\
(0.89)\end{array}$ \\
\hline Manufacturing capital $Q=G_{0} W_{0}+U_{f a}$ & 10833.42 & 8687.74 & 16100.12 \\
\hline \multicolumn{4}{|c|}{ Criteria of operation cycle } \\
\hline Capitalization criterion $\lambda=V_{s v} / G_{0} W_{0}$ & 1.30 & 1.55 & 1.56 \\
\hline Investment criterion $M=D_{0} / U$ & 0.17 & 0.25 & $0.12(0.25)$ \\
\hline Resources criterion $\rho=Q / G_{0} W_{0}$ & 2.82 & 3.59 & 5.59 \\
\hline Characteristic of operation cycle $k_{0}=G_{0} W_{0} / U$ & 0.55 & 0.39 & 0.22 \\
\hline Conversion criterion $\vartheta=\frac{V_{s v}}{Q}=\frac{\lambda}{\rho}=\frac{k_{0}+M}{k_{0}+1}$ & 0.46 & 0.46 & $0.28(0.46)$ \\
\hline Cost of equity capital, $A, 19.04 .2006$, mln USD & 7892.94 & 13964.22 & 7452.80 \\
\hline
\end{tabular}

S o u r c e. Taken from [12-14].

The data analysis in Tab. 1 shows that the level of conversion at the Novolipetsky and Magnitogorsky metallurgical enterprises equals 0.46. As for Severstal, the conversion criterion is almost twice less and is equal to 0.28 . This is because the internal estimate of the fixed asset value has been overstated by 2 times.

Graphical interpretation of the manufacturing capital conversion in a closed operating cycle in a manufacturing and technological system. The conversion of the manufacturing capital $Q$ in a manufacturing and technological system that is an integrated set of technological processes is achieved in a closed operating cycle for the purpose of capitalizing technological costs $G_{0} W_{0}$ in their monetary equivalent in the form of product sales volume $V_{s v}$, tax payment in all level budgets and net income $D_{0}$ necessary and sufficient for investing simple and expanded reproduction of the main funds $U_{m f}$ and the formation of net profit $P_{0}$ in dividend volume for business owners.

Each parameter of the operating cycle is a cash flow with magnitude and direction; therefore, from the standpoint of mathematical theory they are vectors.

The conversion of a closed operating cycle is formed by five vectors $V_{s v}, D_{0}, G_{0} W_{0}, U_{m f}$ and $Q$ [2]. The first contour of the operating cycle that is 'capitalization' consists of three vectors $V_{s v}$, $G_{0} W_{0}$ and $D_{0}$, while the second contour that is 'manufacturing' includes the vectors $Q, G_{0} W_{0}$ and $U_{m f}$

The graphical interpretation of converting a closed operating cycle formed of three vectors is a triangle. Therefore, the graphical interpretation of a basic (ideal) conversion of a closed operating cycle has the form [5]: 


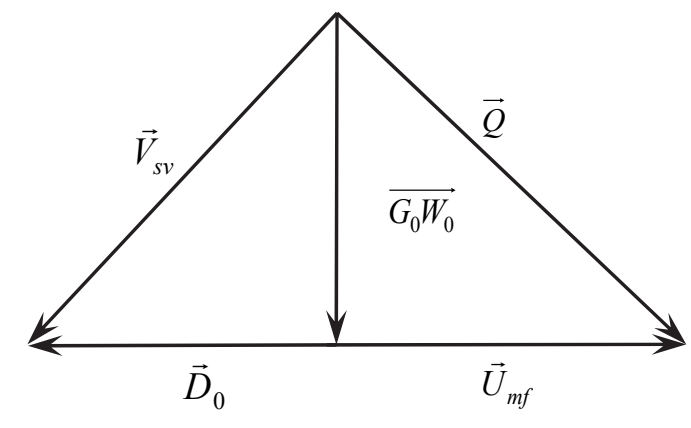

Fig. 2. Basic (ideal) conversion of the operating cycle of manufacturing capital in engineering business

Here $\vartheta=\frac{V_{s v}}{Q}=1$ is the conversion criterion; $\lambda=\frac{V_{s v}}{G_{0} W_{0}}=2$ is the capitalization criterion; $\rho=\frac{Q}{G_{0} W_{0}}=2$ is the resource criterion of manufacturing capital; $\quad M=\frac{D_{0}}{U_{m f}}=1 \quad$ is the investment criterion; $\quad k_{0}=\frac{G_{0} W_{0}}{U_{m f}}=1 \quad$ is the characteristic of the manufacturing and technological system.

Our studies have shown (Tab. 1) that the conversion level of the manufacturing capital in an operating cycle of a real technological system is $\vartheta<1$ (for metallurgical enterprises $\vartheta=0.46)$.

Consequently, the graphical interpretation of converting the manufacturing capital in a closed operating cycle has the form [5]:

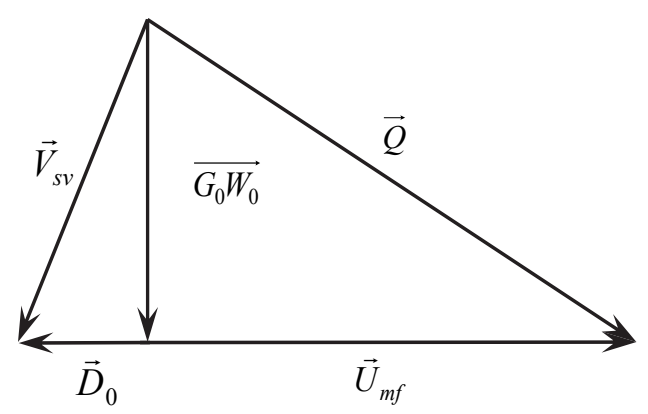

Fig. 3. Closed operating cycle of converting the manufacturing capital in a real engineering business
Here $\vartheta=\frac{V_{s v}}{Q}<1$ is the conversion criterion; $\lambda=\frac{V_{s v}}{G_{0} W_{0}}>1$ is the capitalization criterion; $\rho=\frac{Q}{G_{0} W_{0}}>1$ is the resource criterion of the manufacturing capital; $\quad M=\frac{D_{0}}{U_{m f}}<1 \quad$ is the investment criterion; $k_{0}=\frac{G_{0} W_{0}}{U_{m f}}<1 \quad$ is the characteristic of the manufacturing and technological system.

The business whose conversion criterion of a closed operating cycle is more than unity is an excise one. Fig. 4 presents the graphical interpretation of this cycle [5].

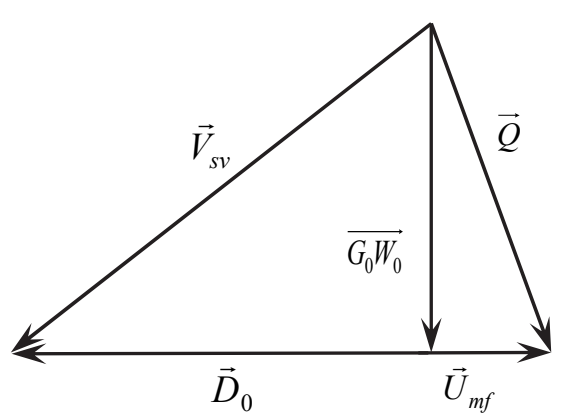

Fig. 4. Closed operating cycle in an excise business

Here $\vartheta=\frac{V_{s v}}{Q}>1$ is the conversion criterion; $\lambda=\frac{V_{s v}}{G_{0} W_{0}}>1$ is the capitalization criterion; $\rho=\frac{Q}{G_{0} W_{0}}>1$ is the resource criterion of the manufacturing capital; $\quad M=\frac{D_{0}}{U_{m f}}>1$ is the investment criterion; $k_{0}=\frac{G_{0} W_{0}}{U_{m f}}>1$ is the characteristic of the manufacturing and technological system.

The flowchart for the system of management accounting with transferred operation costs and values (consumer properties) in zones of financial responsibility [15] is presented in Fig. 5. 


$$
\begin{gathered}
\rightarrow V_{s v 1} \rightarrow V_{s v 2}=\sum_{n=1}^{n=2} V_{s v n} \rightarrow V_{s v 3}= \\
=\sum_{n=1}^{n=3} V_{s v n} \rightarrow V_{s v 4}=\sum_{n=1}^{n=4} V_{s v n} \\
\left(G_{0} W_{0}\right)=\left(G_{0} W_{0}\right)_{1} \rightarrow\left(G_{0} W_{0}\right)_{2}= \\
\rightarrow \sum_{n=1}^{n=2}\left(G_{0} W_{0}\right)_{n} \rightarrow\left(G_{0} W_{0}\right)_{3}=\sum_{n=1}^{n=3}\left(G_{0} W_{0}\right)_{n} \rightarrow \\
D_{0}=D_{01} \rightarrow D_{4}=\sum_{n=1}^{n=4}\left(G_{0} W_{0}\right)_{n}=\sum_{n=1}^{n=2} D_{0 n} \rightarrow D_{03}= \\
=\sum_{n=1}^{n=3} D_{0 n} \rightarrow D_{04}=\sum_{n=1}^{n=4} D_{0 n} \\
Q=Q_{1} \rightarrow Q_{2}=\sum_{n=1}^{n=2} Q_{n} \rightarrow Q_{3}= \\
=\sum_{n=1}^{n=3} Q_{n} \rightarrow Q_{4}=\sum_{n=1}^{n=4} Q_{n} \\
U=U_{1} \rightarrow U_{2}=\sum_{n=1}^{n=2} U_{n} \rightarrow U_{3}= \\
=\sum_{n=1}^{n=3} U_{n} \rightarrow U_{4}=\sum_{n=1}^{n=4} U_{n}
\end{gathered}
$$

Fig. 5. Flowchart of the transfer of operating cycle parameters required for manufacturing products with competitive advantages on the market

Fig. 6 presents the graphical interpretation of the manufacturing capital conversion of an engineering business based on transferring technological costs and consumer properties (value) of products within 4 zones of financial responsibility being technological stages.

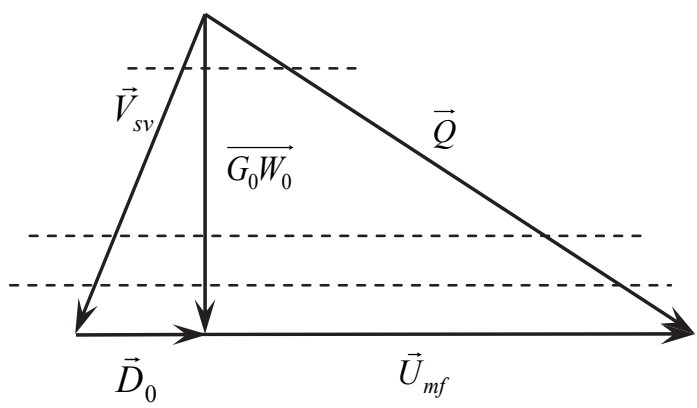

Fig. 6. Conversion of the operating cycle of the manufacturing capital within 4 zones of financial responsibility being technological stages
The borders of technological stages (zones of financial responsibility) are shown as dashed lines.

Study results. The creative model for graphical design of converting the manufacturing capital in an engineering business integrates the production process in the engineering business (internal factor of the conversion process) with the performance of the business in the market (external influence on the engineering business). Product innovations improve the external contour of the operating cycle and technological innovations enhance the internal processes. Both kinds of innovations form intangible assets in the main funds of manufacturing capital in a manufacturing-technological system.

The creative model is presented in the form:

1) parametrical (5) and criterial (7) equations of a closed (continuous) operating cycle of converting the manufacturing capital in the engineering business into the sales volume of products and net income;

2) algorithm for calculating (Tab. 1) the parameters and criteria of conversion on the basis of information received from the stock market about enterprises and their equivalents;

3) algorithm of the graphical design for converting an operating cycle in triangle coordinates (Fig. 2-6).

The graphical design is used to assess the internal cost of tangible and intangible assets in management accounting and in designing innovating projects.

Conclusions and further research. The method of graphical interpretation of the conversion operating cycle of the manufacturing capital into monetary capital in the form and amount equal to sold products is a significant addition to the mathematical model for designing and implementing management accounting.

The results obtained in this study can be used as a basis for:

- developing an algorithm for analyzing and designing scenarios of routing technologies to manufacture products where each technological stage of this product should have a market value, for example, at metallurgical enterprises;

- developing scenarios of designing a production system manufacturing several products in one market sector for a joint stock company, for example, JSC GASPROM. 
The graphical interpretation of converting capitals in an operating cycle will be used in the theory and practices of engineering business similar to the graphical interpretation of converting energy in a thermodynamic cycle. The difference between these conversion processes is that the cycle of thermodynamic conversion of energy is formed by two isotherms and two adiabats in the Cartesian coordinate system, while the conversion of an operating cycle of capitals is formed by five vectors of monetary flows in a right-angled coordinate system. In the first case the conversion is characterized by the coefficient of useful activity and in the second case by the conversion level.

Our future research will be dedicated to developing a conversion method based on the transfer principle which might be used as a tool for designing and managing innovative projects in the engineering business.

\section{REFERENCES}

1. Shichkov A.N., Kremlyova N.A., Polovinkina V.D. Concept of Formation of Infrastructure of Municipal Market of Engineering Knowledge. St. Petersburg State Polytechnical University Journal. Economics, 2015, no. 2(216), pp. 52-59. DOI: 10.5862/JE.216.6

2. Shichkov A.N., Kremlyova N.A., Borisov A.A. Designing the operation cycle of a manufacturingtechnological system. St. Petersburg State Polytechnical University Journal. Economics, 2016, no. 2(240), pp. 89-97. DOI: $10.5862 /$ JE.240.9

3. Shichkov A.N. Teoriia i praktika inzhenernogo biznesa i menedzhmenta. Vologda: VoGU, 2016. 131 s. (rus)

4. Shichkov A.N. Designing ManufacturingTechnological Systems. Scientific Israel-Technological Advantages, 2016, vol. 18, no. 1, pp. 89-106.

5. Shichkov A.N. Innovative Enhancement of an Engineering Business: Operation Cycle Method. Scientific Israel-Technological Advantages, 2016.

6. Restrukturizatsiia ekonomiki: teoriia i instrumentarii: monogr. Pod red. A.V. Babkina. $\mathrm{SPb}$.: Izd-vo Politekhn. un-ta, 2015. S. 664. (rus)

7. AO «Vologodskii zavod stroitel'nykh konstruktsii i dorozhnykh mashin»: ofits. sait. URL: http://dormash. com (data obrashcheniia: 18.08.2016). (rus)

8. Solov'eva D.N. Parametry otsenki potrebitel'skikh svoistv produktsii $\mathrm{v}$ denezhnom vyrazhenii : mater. region. nauch. konf. VIII Ezhegodnoi nauch. sessii aspirantov i molodykh uchenykh. 2015. T. 1: Tekhnicheskie nauki. Ekonomicheskie nauki. S. 353356. (rus)
9. Tukkel' I.L., Golubev S.A., Surina A.V., Tsvetkova N.A. Metody i instrumenty upravleniia innovatsionnym razvitiem promyshlennykh predpriiatii. Pod red. I.L. Tukkelia. SPb.: BKhV-Peterburg, 2013. 208 s. (rus)

10. Shichkov A.N. The Content of the High Engineering Education. World Applied Science, 2013, vol. 27 (Education, Law, Economics, Language and Communication), pp. 343-348.

11. Shichkov A.N. Fiziko-matematicheskaia model' operatsionnogo menedzhmenta $\mathrm{v}$ proizvodstvennotekhnologicheskikh sistemakh inzhenernogo biznesa. Vestnik Vologodskogo gosudarstvennogo universiteta. 2015. Vyp. 5/15. S. 36-41. (rus)

12. Severstal' - Godovye otchety. URL: https:// www.severstal.com/rus/ir/results reports/annual_repor ts/index.phtml (data obrashcheniia: 18.08.2016). (rus)

13. NMLK - Godovye otchety. URL: http://nl mk.ru/investor-relations/reporting-center/annualreports/ (data obrashcheniia: 18.08.2016). (rus)

14. Magnitogorskii metallurgicheskii kombinat Godovye otchety. URL: http://mmk.ru/for investor/ annual_reports/ (data obrashcheniia: 18.08.2016). (rus)

15. Shichkov A.N. Designing of Innovative Tasks for Manufacturing-Technological Systems. Fundamental and Applied Studies in the Pacific and Atlantic Oceans Countries: papers and commentaries of The 1st International Academic Congress. Japan, Tokyo, 25 October 2014. Tokyo University Press, pp. 159165. (rus)

\section{СПИСОК ЛИТЕРАТУРЫ}

1. Шичков А.Н., Кремлёва Н.А., Половинкина В.Д. Концепция формирования муниципального рынка инженерных знаний // Научно-технические ведомости Санкт-Петербургского государственного политехнического университета. Экономические науки. 2015. № 2(216). С. 52-59. DOI: 10.5862/JE. 216.6

2. Шичков А.Н., Кремлёва Н.А., Борисов А.А. Проектирование операционного цикла производ- ственно-технологической системы // Научнотехнические ведомости Санкт-Петербургского государственного политехнического университета. Экономические науки. 2016. № 2(240). С. 89-97. DOI: $10.5862 /$ JE.240.9

3. Шичков А.Н. Теория и практика инженерного бизнеса и менеджмента. Вологда: ВоГУ, 2016. $131 \mathrm{c}$

4. Shichkov A.N. Designing Manufacturing- 
Technological Systems // Scientific Israel-Technological Advantages, 2016, vol. 18, no. 1, pp. 89-106.

5. Shichkov A.N. Innovative Enhancement of an Engineering Business: Operation Cycle Method. Scientific Israel-Technological Advantages, 2016.

6. Реструктуризация экономики: теория и инструментарий: моногр. / под ред. А.В. Бабкина. СПб.: Изд-во Политехн. ун-та, 2015. С. 664.

7. АО «Вологодский завод строительных конструкций и дорожных машин»: офиц. сайт. URL: http://dormash.com (дата обращения: 18.08.2016).

8. Соловьева Д.Н. Параметры оценки потребительских свойств продукции в денежном выражении : матер. регион. науч. конф. VIII Ежегодной науч. сессии аспирантов и молодых ученых. 2015. T. 1: Технические науки. Экономические науки. C. $353-356$.

9. Туккель И.Л., Голубев С.А., Сурина А.В., Цветкова Н.А. Методы и инструменты управления инновационным развитием промышленных предприятий / под ред. И.Л. Туккеля. СПб.: БХВПетербург, 2013. 208 с.

10. Shichkov A.N. The Content of the High Engi- neering Education // World Applied Science, 2013, vol. 27 (Education, Law, Economics, Language and Communication), pp. 343-348.

11. Шичков А.Н. Физико-математическая модель операционного менеджмента в производственно-технологических системах инженерного бизнеса // Вестник Вологодского государственного университета. 2015. Вып. 5/15. С. 36-41.

12. Северсталь - Годовые отчеты. URL: https:// www.severstal.com/rus/ir/results_reports/annual_repor ts/index.phtml (дата обращения: 18.08.2016).

13. НМЛК - Годовые отчеты. URL: http://nlmk $\mathrm{ru}$ /investor-relations/reporting-center/annual-reports/ (дата обращения: 18.08.2016).

14. Магнитогорский металлургический комбинат Годовые отчеты. URL: http://mmk.ru/ for_investor/ annual_reports/ (дата обращения: 18.08.2016).

15. Shichkov A.N. Designing of Innovative Tasks for Manufacturing-Technological Systems. Fundamental and Applied Studies in the Pacific and Atlantic Oceans Countries: papers and commentaries of The 1st International Academic Congress. Japan, Tokyo, 25 October 2014. Tokyo University Press, pp. 159-165.

KREMLYOVA Natal'ia A. - Vologda State University.

160000. Lenina str. 15. Vologda. Russia. E-mail: kremleva-n@yandex.ru

КРЕМЛЁВА Наталия Анатольевна - доцент Вологодского государственного университета, кандидат экономических наук.

160000, ул. Ленина, д. 15, г. Вологда, Россия. E-mail: kremleva-n@yandex.ru

BORISOV Aleksandr A. - Vologda State University.

160000. Lenina str. 15. Vologda. Russia. E-mail: uiiop@mh.vstu.edu.ru

БОРИСОВ Александр Алексеевич - доцент Вологодского государственного университета, кандидат экономических наук.

160000, ул. Ленина, д. 15, г. Вологда, Россия. E-mail: uiiop@mh.vstu.edu.ru

FROLOV Aleksandr A. - Vologda State University.

160000. Lenina str. 15. Vologda. Russia. E-mail: fa@mh.vstu.edu.ru

ФРОЛОВ Александр Анатольевич - доцент, декан Вологодского государственного университета, кандидат технических наук.

160000, ул. Ленина, д. 15, г. Вологда, Россия. E-mail: fa@mh.vstu.edu.ru 